\title{
METHODOLOGY FOR FORMING AND IMPLEMENTING A TOUR AND DETERMINING ITS ECONOMIC EFFICIENCY
}

\author{
МЕТОДИКА ФОРМУВАННЯ І РЕАЛІЗАЦІї ТУРУ \\ ТА ВИЗНАЧЕННЯ ЙОГО ЕКОНОМІЧНОЇ ЕФЕКТИВНОСТІ
}

UDC 338.48

DOI: https://doi.org/10.32843/infrastruct55-18

\section{Krasnoded Tetiana}

Candidate of Economic Sciences,

Associate Professor,

Associate Professor at Department

of Business Consulting

and International Tourism

Dmytro Motornyi Tavria State

Agrotechnological University

Bakina Tetiana

Candidate of Economic Sciences,

Associate Professor,

Associate Professor at Department

of Business Consulting

and International Tourism

Dmytro Motornyi Tavria State

Agrotechnological University

Zakharchenko Olena

Candidate of Economic Sciences,

Senior Lecturer at the Department

of Business Consulting

and International Tourism

Dmytro Motornyi Tavria State

Agrotechnological University
The relevance of the study of issues in the context of tour operator activity is determined. Important issues of formation and promotion of the tour as the main component of tourist products are considered. A tour project is presented and an algorithm for creating a tourist product for several days for a specific tourist destination is demonstrated. The mechanism for determining the cost of a tour is revealed, which includes the cost of accommodation, meals, travel, excursion services and entertainment, support, insurance and other additional services provided to consumer tourists within the framework of a tourist project. At the same time, a mechanism for calculating individual elements of the tour price is presented. The method of calculating the company's profit and economic efficiency from the sale of the tour is revealed. General marketing directions in tourism are also proposed, which can be used to determine the preferences of tourists, present and promote almost all tourist products.

Key words: tour operations, travel company, travel products, tour, cost of the tour, profitability, advertising, agency network, marketing question naire.

В статье определена актуальность исследования вопросов в контексте туроператорской деятельности. Рассмотрены важные вопросы формирования и продвижения тура как основной составляющей туристической продукции. Представлены тур-проект и продемонстрирован алгоритм создания туристического продукта на несколько дней на конкретной туристической дестинации. Раскрыт механизм определения себестоимости тура, в состав которой входит стоимость проживания, питания, проезда, экскурсионного обслуживания и развлечений, сопровождения, страхования и других дополнительных услуг туристам-потребителям в рамках туристического проекта. В то же время представлено механизм расчета отдельных элементов стоимости тура. Раскрыто метод вычисления прибыли и экономической эфрфективности фрирмы от реализации тура. Также предложены общие направления маркетинга в туризме, что можно применять для определения предпочтений туристов, а также презентации и популяризации практически всех туристических продуктов.

Ключевые слова: туроперейтинг, туристическое предприятие, туристическая продукция, тур, себестоимость тура, доходность, реклама, агентская сеть, маркетинговая анкета.

В статті визначено об'єктивну необхідність вивчення методики створення і реалізації туру та визначення його прибутковості в контексті організації туроператорської діяльності в практичній сорері туріндустрії. Розглянуто актуальні питання фрормування та просування туру як основної складової туристичної продукції. Планування та проектування туру - це початкова стадія розробки створення турпродукту, яка безпосередньо грунтується і багато в чому визначається результатами маркетингового дослідження потреб туристичного ринку і пропозицій основних конкурентів на місцевому ринку, що пояснюється спочатку ринковою орієнтацією туроператора. Це питання є актуальним для кожного туроператора, оскільки є стартом його спеціалізованої діяльності. Водночас фрахівцям в галузі туризму також необхідно розуміти механізм фрормування туру на різних туристичних дестинаціях з урахуванням природно-економічних особливостей країни. В статті представлено тур-проект та продемонстровано алгоритм створення туристичного продукту на декілька днів по конкретній туристичній дестинація. Розкрито механізм визначення собівартості туру, до складу якої входить вартість проживання, харчування, проїзу, екскурсійного обслуговування та розваг, супроводження, страхування та інших додаткових послуг, що надаються туристамспоживачам в межах туристичного проекту. Водночас представлено механізм розрахунку окремих елементів вартості туру. Розкрито метод обчислення прибутку та економічної ефрективності фрірми від реалізації туру. В контексті туроператорської діяльності важливим питанням після створення туру залишається питання його популяризації та продажу. Тому в статті також запропоновано загальні напрями маркетингу в туризмі, що можна застосовувати для визначення уподобань туристів та презентації і популяризації практично всіх туристичних продуктів, в тому числі і нових - рекламна компанія, використання розгалуженої системи агентської мережі, маркетингове опитування з метою оптимізації турпродукту.

Ключові слова: туроперейтинг, туристичне підприємство, туристична продукція, тур, собівартість туру, прибутковість, реклама, агентська мережа, маркетингова анкета.

Problem statement. Tourism is a modern global economic industry that accumulates a huge share of financial, socio-cultural, intellectual, labor and other components of resource potential. The study of these components is a necessary condition for their rational and effective use. Therefore, the issues of forming interesting and high-quality tourist products that would meet the needs of modern, fastidious tourists are important and relevant for the study of tour operator activities. This can be fully attributed to the study of the mechanism of creating a tourist product (Stay program) and organizing activities to promote it.
The main task of a travel company-tour operator is to meet the needs of consumers - tourists. Meeting these needs is possible if the travel company applies the mechanism of forming a modern and high-quality tourist product (tour).

Analysis of recent research and publications. Many domestic and foreign practitioners and theorists are interested in the development of tourism and the formation of tourist products. Theoretical issues of tour operations, problems of organization of tourism business and economy of a travel company are well disclosed in the works by such scientists as Baiev V.V., 
Bryl K.H., Diadechko L.P., Kyfiak V.F., Malska M.P., Bordun O.U. and others [1-3; 7; 10 ]. Certain aspects of marketing and features of promotion of a tourist product were covered by Ilina O.M., Moyseieva N.K., Nazarkyna V. O., Pravyk Yu.M., Kariahin Yu.O., Tymoshenko Z.I., Demura T.O., Munin H.B. [4-6; 12-14]. At the same time, the methodology of planning and developing tours, as well as organizing trips, is covered in the works of Liubitseva 0.0 ., Mykhailichenko H.I. and many other authors [9; 11]. However, the mechanism of creating and calculating a tour is practically not described in detail in the research.

Setting objectives. The main objective of the article is to demonstrate the economic mechanism for calculating the cost and promotion of a tour in the context of the company's tour operator activities. In accordance with this objective, the main tasks of the work are to form a tourist project, calculate the cost of the tour, determine its economic efficiency and suggest general directions for its popularization and promotion.

Presentation of the main research material. This mechanism is based on the use of margin income of a travel agency, calculation of the cost of a tourist product and directions for its further popularization. Oberjoch ski resort in Germany was chosen as an object for forming a tourist product. Based on this resort, we formed an elementary tour and gave an example of calculating its cost.

Oberjoch captivates with its picturesque views at first sight. It is impossible not to fall in love with the shining mountain peaks and snowy forests. This is the highest mountain resort in Germany. Here a person can especially acutely feel the unity with nature, its beauty and splendor. The resort will be comfortable for snowboarders and skiers, both entry-level skiing and professionals. Therefore, a tour project for this tourist destination is an ideal solution for tour operators working in the sports and recreation tourism market [15-17].

The tour project is called Hospitable Oberjoch. It is designed for 9 days, including flights Kyiv-Munich and Munich-Kyiv:

Day 1. Flight Kyiv-Munich, overnight in Munich.

Day 2. Transfer from Munich airport to the hotel (194 km) by bus, which is located on the territory of the ski resort (4-star Panoramahotel Oberjoch). Breakfast and rest at the hotel. Passing the briefing. Welcome evening program at the hotel.

Day 3. Breakfast. Visit to the ski and snowboard school. Lunch. Rest. Walking through the snowcovered forest.

Day 4. Breakfast. Riding on red, blue, and black tracks with an instructor. Lunch. Rest. Free time. Dinner.

Day 5. Breakfast. Riding on red, blue, and black tracks with an instructor. Lunch. Rest. Free time. Dinner.
Day 6. Breakfast. Riding on red, blue, and black tracks with an instructor. Lunch. Rest. Pub tour with tasting of the best German beers and national dishes. Free time.

Day 7. Breakfast. Sledding, dog sledding, skating, horse-drawn carriage, as well as swimming in the pool. Flying in the air. Lunch and rest. Walking through the local beauty on special walking trails. Dinner.

Day 8. Breakfast. Visit the most beautiful lake in the country - Lake Bodensee. Lunch and rest. Free time. Dinner.

Day 9. Breakfast. Guided tour of ancient Bavarian monasteries and castles of kings. Dinner. Visit to the souvenir shop. Flight from Munich to Kyiv.

Next, we will determine the economic efficiency of the tourist product Hospitable Oberjoh based on the cost indicators of basic and additional services.

1. Determination of the cost of accommodation in a 4-star hotel Panoramahotel Oberjoch: number of people staying in a room -3 people, the cost of a hotel room per tour - 3675 EUR. Cost of accommodation for one tourist on the route: $3675 / 3=1225$ (EUR).

2. Determination of the cost of meals: meals include breakfast, lunch and dinner; the cost of meals for one tourist per day is 175 (EUR), the number of days of the tour is 9 . Calculation of the cost of meals on the route: $175^{\star} 9=1575$ (EUR).

3. Calculation of travel costs: round trip transfer: $120 * 2=240$ (EUR), transfer (meeting, seeing off) 30 EUR, other- 12 EUR. Total amount per 1 person on the tour for travel expenses: $240+30+12=282$ (EUR).

4. Determining the cost of additional service along the route:

- excursion service includes 12 programs. Their total cost per person for the entire tour is 1700 EUR.

5 . The cost of insurance is 31 EUR.

6. The cost of the tour manager is 155 EUR.

7. Calculation of travel agent commission costs: $9 \%$ of 4968 or $0.09 * 4968$, i.e. 447.12 (EUR).

8. The cost of the tour per tourist is calculated based on the total of all expenses incurred (Table 1).

9. Setting the market price of a tour for one tourist: The market price is set using the formula:

$$
P t=C t+P \text {, }
$$

where $P t$ is the price set by the company for the service (excluding VAT 20\%);

$C t$ is the cost of a unit of production, service (tourist product);

$P$ is the acceptable profit per unit of production for this industry.

So, a) acceptable profit for this industry:

$P=5415.12 * 19 \%=1028.87$ (EUR);

b) the price set by the company for a tour for one tourist (excluding VAT)

$\mathrm{Pt}=5415.12+1028.87=6443.99$ (EUR);

C) the price of tourist products for end consumers (Pec), taking into account the VAT rate of $20 \%$, will be: $6443.99+20 \%=7732.79$ (EUR). 
Calculation of the Cost of a Tour Per Tourist

\begin{tabular}{|c|l|c|}
\hline № & \multicolumn{1}{|c|}{ Item of expenditure } & Amount, EUR \\
\hline 1 & Cost of accommodation & 1225 \\
\hline 2 & Cost of meals & 1575 \\
\hline 3 & Cost of transport services & 282 \\
\hline 4 & Excursion service, which includes entrance tickets to museums and other tourist sites & 1700 \\
\hline 5 & Insurance amount & 31 \\
\hline 6 & Expenses for the tour manager & 155 \\
\hline Total cost: & 4968 \\
\hline 7 & Payment of commission to travel agents (9\% of the cost) & 447.12 \\
\hline 8. Total cost of the tour per tourist (Ct): & 5415.12 \\
\hline
\end{tabular}

Source: conditional indicators

10. Planning the sold tours based on marketing research:

The number of sold group tours will be 52 tours, the number of people in a group - 14. That is, it is planned to sell 52 group tours of 14 people per year, in total, 728 individual tours (Ntur) will be sold in this way during the year.

11. Calculation of margin income $(\mathrm{Im})$ from the number of sold tours:

$$
\text { Im }=P * \text { Ntur. }
$$

So, $I m=1028.87 * 728$ rounds $=749017.36$ (EUR).

12. Determination of the annual gross profit (AGP) that will be received by the company for this tourist product.

In addition to the direct costs included in the cost of the tour, the company also has fixed costs for organizing and selling this and other tours. The amount of fixed cost for this tour will be 120 EUR.

If we know the amount of annual margin income (AIm) and the amount of fixed expenses for the year (FC), we can determine the annual gross profit (AGP):

$$
A G P=A I m-F C * 12 \text {. }
$$

So, $A G P=749017.36-120 * 12$ months $=$ 747577.36 (EUR).

13. Determination of the company's net profit (NP) for this tourist product:
To determine net profit, it is necessary to deduct income tax from gross profit (the base rate applicable in Ukraine is $18 \%$ ):

$$
N P=A G P-I T,
$$

where $I T$ is the income tax.

So, $N P=747577.36-18 \%=613013.44$ (EUR).

14. Assessment of the economic efficiency of a new product using indicators of profitability of products:

The profitability indicator of a new product or service (Pnp) is calculated using the formula:

$$
P I=A G P / S t p * 100 \% \text {, }
$$

Stp is the amount of sales of a new tourist product, service, or cash units;

$$
\text { Stp }=P e c * \text { Ntur. }
$$

So, $\operatorname{Stp}=7732.79 * 728$ tours $=5629471.12$ (EUR);

Pnp $=747577.36 / 5629471.12 * 100 \%=13.3 \%$.

The profitability ratio $(\mathrm{PR})$ is calculated using the formula:

$$
P R=N P / S t p * 100 \% .
$$

So, $P R=613013.44 / 5629471.12 * 100 \%=10.9 \%$.

Thus, it is possible to form generalizing information on calculating the cost and economic efficiency of the tourist product Hospitable Oberjoch (Table 2).

If consumers' expectations for tourist experiences are not met, they can switch to buying tours from other travel operators. This will affect the travel agency's profits. Therefore, after forming a tour, the next main

Table 2

Cost of a Tourist Product and Indicators of its Economic Efficiency

\begin{tabular}{|l|c|}
\hline \multicolumn{1}{|c|}{ Indicator name } & Digital indicator value \\
\hline Total cost of the tour per tourist, Ct & $5415.12 \mathrm{EUR}$ \\
\hline Acceptable profit per unit of production (added value) for a this industry, P & $1028.87 \mathrm{EUR}$ \\
\hline The price set by the company for a tour for one tourist without VAT, Pt & $6443.99 \mathrm{EUR}$ \\
\hline Price of the sold tour for the end consumer including VAT, Pec & $7732.79 \mathrm{EUR}$ \\
\hline Number of sold tours per year, Ntur & 728 \\
\hline Margin income from the number of sold tours, Im & $749017.36 \mathrm{EUR}$ \\
\hline Annual gross profit of the company, for this tourist product, AGP & $747577.36 \mathrm{EUR}$ \\
\hline Net profit of the company for this tourist product, NP & $613013.44 \mathrm{EUR}$ \\
\hline Profitability indicator, PI & $13.3 \%$ \\
\hline Profitability ratio, PR & $10.9 \%$ \\
\hline
\end{tabular}

Source: authors' calculations 
task of the tour operator is to promote that and sell to the end consumer. In other words, it is necessary to apply a travel product marketing system.

First of all, it is necessary to use descriptive advertising of tourist products - catalog advertising with vivid visual accompaniment and in the mass media. It is necessary to note the main characteristics of the resort and its competitive advantages. The use of many advertising mechanisms will not be useful without using an extensive agency network system, since the tour operator company itself is a wholesale service provider and does not have direct contact with small consumers and needs the services of intermediaries. For this purpose, there are travel agencies and permanent active agents. In the context of selling a tour, further improvement is desirable. To implement this component, the tour operator or agencies should develop a questionnaire. This questionnaire will provide an opportunity to study potential consumers, their motives and goals of recreation in order to improve and form a high-quality and comprehensive tourist product.

To identify the wishes of the consumer of a tourist product who is interested in ski resorts in order to improve the tourist product Hospitable Oberjoch in Germany, a questionnaire with the following questions is offered:

1. Do you like your vacation in Germany?

2. What do you like about winter ski resorts?

3. Do you like mountain winter resorts in Germany? Why?

4. What class of Hotel is desirable for you?

5. How many people do you usually plan a vacation for?

6. What do you like about a ski resort other than skiing?

7. What kind of cuisine do you like?

8. Is it interesting to visit other places while vacationing in a ski resort?

9. Do you have any special requests for a ski tour?

10 . What daily routine are you used to on vacation? and so on.

Conclusions. The mechanism of formation and promotion of a tourist product used on the example shows that it is efficient and cost-effective for the tour operator. The tour will be interesting for tourists who like clean air and winter sports, especially in the context of family holidays. Advertising of the resort, which can be applied by the agency network, clearly demonstrates its competitive advantages. The consumer questionnaire will help the travel company identify the wishes of potential tourists, which can be taken into account when improving the tourist product.

\section{REFERENCES:}

1. Baiev V.V. (2016) Osnovy turopereitynhu: navch. posib. [Basics of tour operations: a textbook]. Kyiv: Personal. (in Ukrainian)
2. Bryl K.H. (2017) Opornyi konspekt lektsii z kursu «Turopereitynh» dlia studentiv vsikh form navchannia napriamu pidhotovky 242 «Turyzm». [Reference summary of lectures on the course "Tour operations" for students of all forms of study in the direction of training 242" Tourism»]. Chernihiv: ChNTU. (in Ukrainian)

3. Diadechko L.P. (2007) Ekonomika turystychnoho biznesu. Navchalnyi posibnyk. [Economy of the tourism business. Training manual]. Kyiv: Tsentr uchbovoi literatury. (in Ukrainian)

4. Ilina E.N. (2008) Turopereyting: organizatsiya deyatel'nosti: ucheb. dlya vuzov turist. profilya [Tour operations: organization of activities: textbook for universities of tourism profile]. Moscow: Finansy i statistika. (in Russian)

5. Ilina E. N. (2008) Turopereyting: organizatsiya deyatel'nosti: ucheb. dlya vuzov turist. profilya [Tour operations: tourist product promotion: tutorial]. Moscow: Finansy i statistika. (in Russian)

6. Kariahin Yu.O., Tymoshenko Z.I., Demura T.O., Munin H.B. (2009) Marketynh turproduktu. Pidruchnyk. [Marketing of travel products. Textbook]. Kyiv: Kondor.

7. Kyfiak V.F. (2003) Orhanizatsiia turystychnoi diialnosti $\vee$ Ukraini [Organization of tourism activities in Ukraine]. Chernivtsi: Knyhy-XXI. (in Ukrainian)

8. Krasnodied T., Bakina T., Popova T., Zakharchenko O. (2021) Ekonomichnyi mekhanizm rozrakhunku vartosti ta prosuvannia turu v konteksti turoperatorskoi diialnosti pidpryiemstva [Economic mechanism for calculating the cost and promotion of a tour in the context of the company's tour operator activities]. Socio-economic and management concepts: collective monograph. Boston: Primedia eLaunch. (in Ukrainian)

9. Liubitseva O.O. (2003) Metodyka rozrobky turiv: navch. posib. [Methods of developing tours : textbook]. Kyiv: Alterpres. (in Ukrainian)

10. Malska M.P., Bordun O.Yu. (2012) Orhanizatsiia ta planuvannia diialnosti turystychnykh pidpryiemstv: teoriia ta praktyka. Navch. posib. [Organization and planning of tourist enterprises: theory and practice. Textbook]. Kyiv: Tsentr uchbovoi literatury. (in Ukrainian)

11. Mykhailichenko H.I. (2003) Praktyka orhanizatsii turystychnykh podorozhei: navch. posib. [Practice of organizing tourist trips: textbook]. Kyiv: KNTEU. (in Ukrainian)

12. Moyseeva N.K. (2009) Marketynh y turbyznes: uchebnyk [Marketing and travel business: textbook]. Moscow: Sovetskyi sport. (in Russian)

13. Nazarkyna V. A. (2009) Marketynh v sotsyalnokulturnom servyse y turyzme: uchebnoe posobye [Marketing in socio-cultural service and tourism: a textbook]. Novosibirsk. (in Russian)

14. Pravyk Yu.M. (2008) Marketynh turyzmu: pidruchnyk [Tourism marketing: a textbook]. Kyiv: Znannia. (in Ukrainian)

15. Oberjoch - Aktualisierte Reviews. Available at: https://seetheworld.top/hirskolyzhnyj-kurort-oberjokhoberjoch-nimechchyna.

16. Oberjoch Ski Resort. Available at: http://www.arrivo.ru/germaniya/gornolyzhnyiy-kurortoberiyoh.html.

17. Dein Basecamp in den Alpen - Fair Storno zum besten Preis. Available at: https://www.booking.com/ hotel/de/panoramahotel-oberjoch.ru.html?aid. 
БІБЛІОГРАФІЧНИЙ СПИСОК:

1. Баєв В.В. Основи туроперейтингу: навч. посіб. Київ : ДП “Вид. дім “Персонал”, 2016. 156 с.

2. Бриль К.Г. Опорний конспект лекцій з курсу «Туроперейтинг» для студентів всіх фрорм навчання напряму підготовки 242 «Туризм» Чернігів : ЧНТУ, 2017249 c.

3. Дядечко Л.П. Економіка туристичного бізнесу. Навчальний посібник. Київ : Центр учбової літератури, 2007. 224 с.

4. Ильина Е.Н. Туроперейтинг: организация деятельности: учеб. для вузов турист. просиля. Рос. междунар. акад. туризма. 2-е изд., перераб. и доп. Москва : Финансы и статистика, 2008. -241 с.

5. Ильина Е.Н. Туроперейтинг: продвижение туристского продукта : учебник. Москва : Финансы и статистика, 2008. 176 с.

6. Карягін Ю.О., Тимошенко 3.І., Демура Т.О., Мунін Г.Б. Маркетинг турпродукту. Підручник. Київ : Кондор, 2009. 394 c.

7. Киффяк В.Ф. Організація туристичної діяльності в Україні. Чернівці : Книги-XXI, 2003. 300 с.

8. Краснодєд Т., Бакіна Т., Попова Т., Захарченко О. Економічний механізм розрахунку вартості та просування туру в контексті туроператорської діяльності підприємства. Socio-economic and management concepts: collective monograph / Krupelnytska I., etc. International Science Group. Boston : Primedia eLaunch,
2021. 660 p. DOI: 10.46299/ISG.2021.MONO.ECON. IURL (C. 297-301).

9. Любіцева О.О. Методика розробки турів : навч. посіб. Київ : Альтерпрес, 2003. 104 с.

10. Мальська М.П., Бордун О.Ю. Організація та планування діяльності туристичних підприємств: теорія та практика. Навч. посіб. Київ : Центр учбової літератури, 2012. 248 c.

11. Михайліченко Г.І. Практика організації туристичних подорожей : навч. посіб. Київ : КНТЕУ, 2003. $156 \mathrm{c}$.

12. Моисеева Н.К. Маркетинг и турбизнес: учебник. Москва : Советский спорт, 2009. 496 с.

13. Назаркина В.А. Маркетинг в социальнокультурном сервисе и туризме: учебное пособие / В.А. Назаркина [и др.]; Новосиб. гос. техн. ун-т. Новосибирск, 2009. 82 с.: табл.

14. Правик Ю.М. Маркетинг туризму: підручник . Київ : Знання, 2008. 303 с.

15. Oberjoch - Aktualisierte Reviews. URL: https://seetheworld.top/hirskolyzhnyj-kurort-oberjokhoberjoch-nimechchyna.

16. Горнолыжный курорт Оберйох. URL: http://www.arrivo.ru/germaniya/gornolyzhnyiy-kurortoberiyoh.html.

17. Dein Basecamp in den Alpen - Fair Storno zum besten Preis. URL: https://www.booking.com/hotel/de/ panoramahotel-oberjoch.ru.html?aid. 